\title{
Effects of Cooling Temperature and Duration on Flowering of the Nobile Dendrobium Orchid
}

\author{
Christine Yung-Ting Yen ${ }^{1}$ and Terri W. Starman ${ }^{2,5}$ \\ Department of Horticultural Sciences, 2133 TAMU, Texas A\&M University, \\ College Station, TX 77843-2133
}

\author{
Yin-Tung Wang ${ }^{3}$ \\ Department of Horticultural Sciences, Texas A\&M University System, Texas \\ AgriLife Research and Extension Center at Weslaco, 2415 East Highway 83, \\ Weslaco, TX 78596
}

\section{Genhua Niu ${ }^{4}$ \\ Department of Horticultural Sciences, Texas AgriLife Research and Extension Center at El Paso, 1380 A\&M Circle, El Paso, TX 79927}

Additional index words. cooling requirement, Dendrobium nobile, flower induction, flower initiation

\begin{abstract}
The effects of cooling temperature [constant $\left(10,13,15\right.$, or $18{ }^{\circ} \mathrm{C}$, or 15,18 , or $\left.\left.21^{\circ} \mathrm{C}\right)\right]$ and duration $(2,3,4,5$, or 6 weeks, or $3,4,5,6$, or 7 weeks) at two separate locations (College Station and Weslaco, TX) on growth and flowering of Dendrobium Sea Mary 'Snow King', a Dendrobium nobile Lindl. hybrid, were investigated and the cooling requirement for flowering was quantified. Interactions between temperature and cooling duration were significant on time required to reach anthesis from either the beginning or completion of cooling, average flower number per flowering node, and percentage of nodes with aborted buds. Increasing cooling duration from 2 to 6 or 3 to 7 weeks resulted in less time to reach anthesis after the completion of cooling. However, the increased cooling durations extended the time needed for producing a flowering crop. Plants cooled at a relatively higher temperature among 10,13 , and $15^{\circ} \mathrm{C}$ required less time to reach anthesis after the completion of cooling. Plants had more flowering nodes and total flowers when cooled at 10,13 , or $15^{\circ} \mathrm{C}$ than at $18^{\circ} \mathrm{C}$ in College Station or at 15 or $18{ }^{\circ} \mathrm{C}$ than at $21^{\circ} \mathrm{C}$ in Weslaco. The results suggest that 3 weeks at $13^{\circ} \mathrm{C}$ has saturated the cooling requirement, and 3 weeks at 13 or $15^{\circ} \mathrm{C}$ is a recommended cooling treatment that saves production cost without retarding flower development.
\end{abstract}

Dendrobium was reported to be the second most valued orchid genus in Japan in 2002 with a market share of $20 \%$, only behind Phalaenopsis with a 30\% market share (Laws, 2004; Wang, 2004). Dendrobium has been the most economically important flowering pot orchid genus in Hawaii with a wholesale value of $\$ 6$ million in both 2005 and 2006 (U.S. Department of Agriculture, 2007). However, the nobile-type dendrobiums, cultivars bred mainly from the species D. nobile (Ichihashi, 1997), are still a relatively new mass-produced commercial crop having a high market potential. Studies

\footnotetext{
Received for publication 25 Mar. 2008. Accepted for publication 6 June 2008 .

We thank the Fred C. Gloeckner Foundation, Norman Fang and his family, and the American Orchid Society for funding the project.

${ }^{1}$ Graduate Research Assistant.

${ }^{2}$ Associate Professor.

${ }^{3}$ Professor. Current address: Matsui Nursery, Salinas, CA.

${ }^{4}$ Assistant Professor.

${ }^{5}$ To whom reprint requests should be addressed; e-mail yintung.wang@gmail.com
}

to determine the cultural requirements are needed to improve the cultivation system and to make year-round flowering.

Dendrobium nobile, the progenitor of nobile-type dendrobium hybrids, is native to habitats ranging from the Himalayas to southeast Asia and much of southern China (Baker and Baker, 1996). Plants must be exposed to moderately low temperatures to induce flowering (Arditti, 1966; Goh et al., 1982; Rotor, 1952, 1959), which usually occurs in the fall or after sudden rainstorms in its habitats. Rotor $(1952,1959)$ reported that D. nobile plants, exposed to $13{ }^{\circ} \mathrm{C}$, produced flowers regardless of photoperiod. The best flowering performance in two nobile dendrobium cultivars, $D$. Snowflake 'Red Star' and $D$. Hinode 'Toutenkou', was achieved when cooling plants at 15 to $20^{\circ} \mathrm{C} /$ 10 to $12.5{ }^{\circ} \mathrm{C}(8 \mathrm{~h}$ day/16 h night $)$ for $40 \mathrm{~d}$ (Sinoda et al., 1988).

Besides the nobile-type dendrobiums, several other dendrobiums also require low temperatures for flower induction. Flower initiation in $D$. phalaenopsis Fitzg. was induced by low temperature of $13{ }^{\circ} \mathrm{C}$ regardless of daylength (Rotor, 1952, 1959). In nature, the inflorescence of $D$. crumenatum
Sw. produces flower buds having nearly fully developed anthers and all other floral parts and then undergoes dormancy. Floral development resumes in the dormant flower buds after a sudden temperature drop of $5{ }^{\circ} \mathrm{C}$ (exact temperature unspecified), which is often associated with rainstorms in southeast Asia (Goh et al., 1982).

The low temperatures that induce flower initiation vary among orchid genera and even differ from one species to another or among hybrids in the same genus. Regardless of daylength, several Cymbidium Sw. hybrids (C. Madeleine, $C$. Doreen, $C$. Zebra, and $C$. No. 2212) and Paphiopedilum insigne Lindl. flowered at a low temperature of $13{ }^{\circ} \mathrm{C}$ (Rotor, 1952, 1959). Nishimura et al. (1976) reported that the transition from vegetative growth to flower development in Phalaenopsis Sea Mist required relatively low temperatures of 15 to $18^{\circ} \mathrm{C}$. Two to 5 weeks of night temperature between 12 and $17{ }^{\circ} \mathrm{C}$ and day temperature not over $27{ }^{\circ} \mathrm{C}$ for flower initiation in Phalaenopsis amabilis Blume and Phalaenopsis schilleriana Rchb. f. was reported by Tran Thanh Van (1974).

Relatively high temperatures may be unfavorable to flower induction. Several Cymbidium hybrids, Paphiopedilum insigne and $D$. nobile plants held at $18^{\circ} \mathrm{C}$, compared with $13{ }^{\circ} \mathrm{C}$, remained vegetative (Rotor, 1952, 1959). Flowering of P. amabilis was inhibited when plants were grown under high temperatures $\left(30{ }^{\circ} \mathrm{C}\right.$ day $/ 23{ }^{\circ} \mathrm{C}$ night $)$ compared with low temperatures at $25^{\circ} \mathrm{C}$ day/ $20{ }^{\circ} \mathrm{C}$ night (Chen et al., 1994). The inflorescence of $P$. amabilis did not emerge when temperature was over $28^{\circ} \mathrm{C}$ (Sakanishi et al., 1980). Wang et al. (2006) observed that when day temperature was maintained at 28 or $30{ }^{\circ} \mathrm{C}$, certain Phalaenopsis hybrids remained vegetative even when night temperature dropped to 19 and $14{ }^{\circ} \mathrm{C}$, respectively. Therefore, if the threshold temperature for initiating flowers, promoting the best flower quality, or that adversely affects plant growth or inhibits flowering is known, flowering can be programmed to meet a specific market time.

The objectives of this study were to quantify the cooling requirement for flower initiation and to define an optimum cooling treatment for producing quality flowering $D$. Sea Mary 'Snow King' plants.

\section{Materials and Methods}

Plant materials and growing conditions. One-year-old liners of Dendrobium Sea Mary 'Snow King', a $D$. nobile hybrid propagated from single-node cuttings and planted in sphagnum moss with an average pseudobulb (i.e., a thickened portion of the stem in orchids functioning as a water and food storage organ) height of 7 to $10 \mathrm{~cm}$, were shipped from Yamamoto Dendrobiums in Mountain View, HI. Plants arrived at Texas A\&M University, College Station on 15 Feb. 2006 and were immediately potted into 10.2$\mathrm{cm}$ (top diameter, $414 \mathrm{~mL}$ vol.) standard green plastic pots and placed in a greenhouse 
having glass walls and a polycarbonate roof. The root substrate consisted of two parts of coarse peat (Sunshine Peat; Sun Gro Horticulture, Bellevue, WA), one part coarse perlite, and one part No. 3 grade diatomite (Diatomite USA, Elma, NY) amended with powdered Micromax (Scotts, Marysville, $\mathrm{OH})$ at $1 \mathrm{~g} \cdot \mathrm{L}^{-1}$ as a source of micronutrients and powdered dolomitic limestone at $5 \mathrm{~g} \cdot \mathrm{L}^{-1}$. A wetting agent, Aqua Gro $2000 \mathrm{G}$ (Scotts), was added to the medium at $0.5 \mathrm{~g} \cdot \mathrm{L}^{-1}$.

Plants were potted with the root substrate packed tightly to secure them in place when lifted up only by the upper portion of the pseudobulbs. Immediately after potting, plants were irrigated with reverse osmosis (RO) water containing fungicides (etridiazole and thiophanate-methyl, Banrot 40\% WP; Scotts) at $0.6 \mathrm{~g} \cdot \mathrm{L}^{-1}$ to prevent root rot. Plants were spaced pot-to-pot in $30.8 \times 51.4-\mathrm{cm}$ molded black plastic carrying trays [4.00 Transport Tray (15); Landmark Plastic Corporation, Akron, $\mathrm{OH}$ ] on the greenhouse bench with leaves orienting east and west to best capture sunlight. The pseudobulbs were supported with bamboo stakes (Bamboo Supply, Lakeland, FL) and twist ties to avoid lodging and minimize mutual shading. Whenever an undesirable second new shoot emerged, it was removed to maintain a single pseudobulb per pot.

Greenhouse irradiance and air temperature at plant canopy level were recorded hourly with data loggers [HOBO (Onset Computer Co., Bourne, MA), WatchDog (Spectrum Technologies, Plainfield, IL), and Apogee line quantum sensors (Apogee Instruments, Logan, UT)] (Fig. 1). Plants were grown in a warm environment (average $25.3{ }^{\circ} \mathrm{C}$ day $/ 23.0{ }^{\circ} \mathrm{C}$ night) under an average $4.9 \mathrm{~mol} \cdot \mathrm{m}^{-2} \cdot \mathrm{d}^{-1}$ photosynthetically active radiation $(P A R)$. The automatic thermal screen system was set to be pulled over when needed to reduce light level, overheating, or severe temperature drop in the greenhouse. Pots were irrigated as needed with a nutrient solution made with RO water and a $15 \mathrm{~N}-$ 2.2P-12.5K (Peters Excel 15-5-15 Cal-Mag; Scotts) water-soluble fertilizer at $0.67 \mathrm{~g} \cdot \mathrm{L}^{-1}$. Plain RO water was used after nutrient application was ended on 1 Sept. 2006. Pesticides [Bacillus thuringiensis (Gnatrol); Valent BioSciences Corporation, Libertyville, IL; azadirachtin (Azatin) and cyfluthrin (Decathlon), OHP, Mainland, PA; imidacloprid (Marathon II), OHP] were applied when necessary to control fungus gnats, caterpillars, and mealy bugs, respectively.

The experiment was a $4 \times 5$ factorial with four cooling temperatures (constant 10, 13, 15 , and $18^{\circ} \mathrm{C}$ ) and five cooling durations (2, $3,4,5$, and 6 weeks). A randomized complete block design with 12 single plant replications was used. A total of 240 vegetatively propagated nobile dendrobium plants were used. Plants were subjected to cooling treatments in growth chambers starting on 13 Nov. 2006. The growth chambers were maintained at $65 \%$ relative humidity and a 12 -h photoperiod with $350 \mu \mathrm{mol} \cdot \mathrm{m}^{-2} \cdot \mathrm{s}^{-1}$ photosynthetic photon flux provided by both fluorescent and incandescent lamps. The average air temperatures recorded in the growth chambers were 9.8 (fluctuation between 9.5 to $10.6^{\circ} \mathrm{C}$ ), 13.3 (fluctuation between 12.8 to $13.9{ }^{\circ} \mathrm{C}$ ), 14.5 (fluctuation between 14.2 to $14.9{ }^{\circ} \mathrm{C}$ ), and $18.0^{\circ} \mathrm{C}$ (fluctuation between 17.1 to $19.3^{\circ} \mathrm{C}$ ), respectively.

Plants were moved back to the warm greenhouse with temperatures averaging $24.3{ }^{\circ} \mathrm{C}$ day/21.9 ${ }^{\circ} \mathrm{C}$ night after the completion of cooling for flower development. The average daily light integral from the end of cooling until full flowering was 6.1 $\mathrm{mol} \cdot \mathrm{m}^{-2} \cdot \mathrm{d}^{-1} P A R$. Twelve plants served as an observational control group (i.e., not

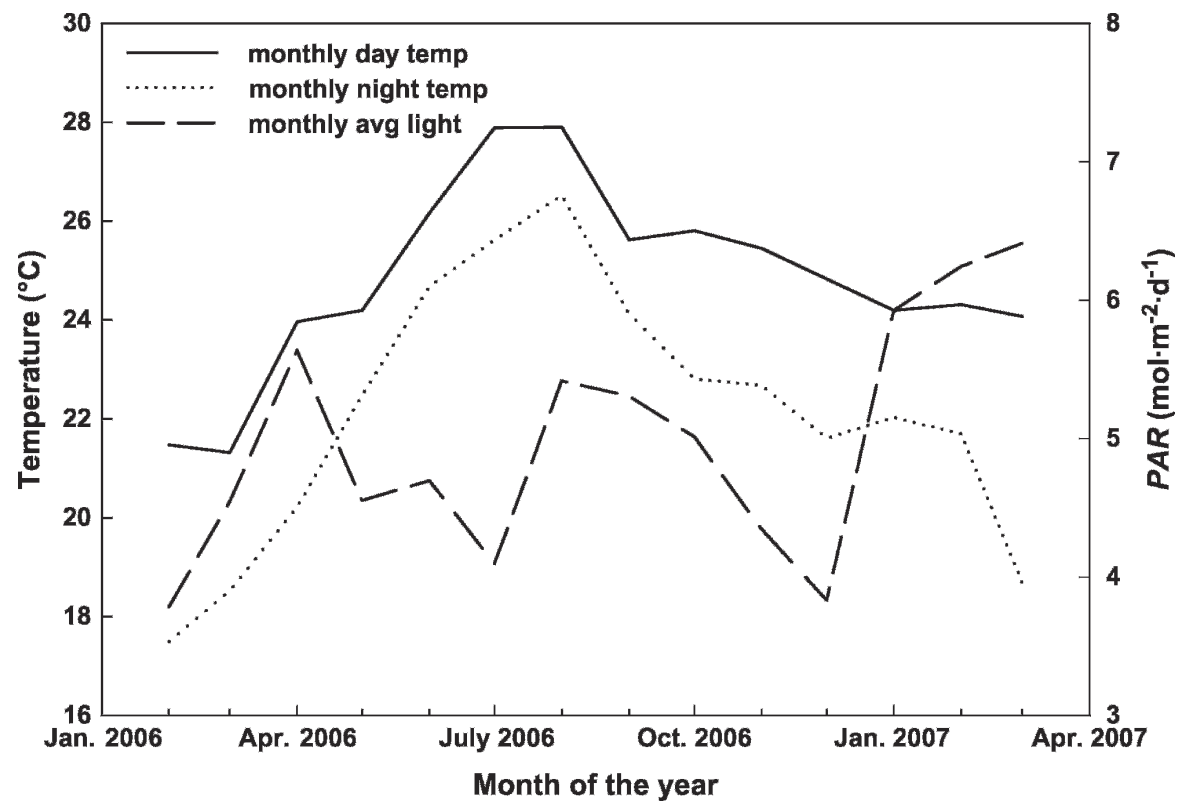

Fig. 1. Average monthly light and air temperature in the greenhouse throughout the experimental period in College Station. included in statistical analysis), continued receiving nutrients at $0.67 \mathrm{~g} \cdot \mathrm{L}^{-1}$ throughout the experimental period, and remained in the greenhouse without cooling.

Experiment in Weslaco. A similar experiment was conducted in Weslaco, TX. All plant materials and cultural treatments were the same as used in College Station unless stated otherwise. The experiment was a $3 \times 5$ factorial with three cooling temperatures (constant 15, 18, and $21^{\circ} \mathrm{C}$ ) and five durations (3, 4, 5, 6, and 7 weeks). A randomized complete block design with 15 replications was used. A total of 225 vegetatively propagated nobile dendrobium plants were used. Plants were subjected to cooling treatments in growth chambers starting on 1 Nov. 2006. The average air temperatures from the end of cooling until full flowering were $26.0^{\circ} \mathrm{C}$ day/ $17.0^{\circ} \mathrm{C}$ night.

Data collection. Starting from 5 Dec. 2007, weekly photographs were taken to compare and record the visual differences among treatments. Data, including time to anthesis (the first flower bud on a plant cracked open) and numbers of nodes, aerial shoots, aborted buds, flowering nodes, and total flowers, were collected. For the time to anthesis, the numbers of days were recorded from completion of the cooling treatments. In addition, the numbers of days from beginning of the cooling treatments were calculated to show total time required from cooling to flowering. Percentage of nodes with aborted buds was calculated by dividing number of aborted buds by number of nodes and multiplying by $100 \%$. Average flower number per flowering node was calculated by dividing total flower number by flowering node number.

Statistical analysis. All data except for those from the observational control group were subjected to analysis of variance, Duncan's multiple range test for comparing the means, and linear regression analysis when necessary, all at $P \leq 0.05$. Percentage data were arcsine-transformed to normalize the distribution of variance before subjecting to statistical analysis. All statistical analysis was performed by SAS 9.1.3 statistical software (SAS Institute, Cary, NC).

\section{Results}

Results from College Station and Weslaco showed that interactions between temperature and cooling duration were significant on time to anthesis from either the beginning or the completion of cooling. From the College Station experiment, regardless of cooling temperature, increasing cooling duration from 2 to 6 weeks decreased the average time needed to reach anthesis (from 49 to 37 d) after plants had been moved from growth chambers to a warm greenhouse (Fig. 2A). As cooling temperature increased from 10 to $18{ }^{\circ} \mathrm{C}$, the difference in time required to reach anthesis from the completion of cooling widened as cooling duration lengthened from 2 to 6 weeks (Fig. 2C). For example, time to anthesis from the completion of cooling for plants that were cooled at 10 , 
13,15 , or $18^{\circ} \mathrm{C}$ had a range of $7 \mathrm{~d}$ (from 49 to $42 \mathrm{~d}$ ), $8 \mathrm{~d}$ (from 46 to $38 \mathrm{~d}$ ), $12 \mathrm{~d}$ (from 46 to $34 \mathrm{~d}$ ), or $19 \mathrm{~d}$ (from 54 to $35 \mathrm{~d}$ ), respectively, when cooling duration increased from 2 to 6 weeks. In Figure 2A, the linear slopes of cooling treatments at $10,13,15$, and $18{ }^{\circ} \mathrm{C}$ changed from $-1.8,-1.9,-3.0$, to -4.6 (significant linear regression at $P \leq 0.001$ ). The higher the cooling temperature, the steeper the slope became. In addition, more time was needed to reach anthesis from the completion of cooling as cooling temperature decreased from 15 to $10{ }^{\circ} \mathrm{C}$ (Fig. 2A, C).

For cooling durations of 2 to 4 weeks, plants that were cooled at 13 or $15{ }^{\circ} \mathrm{C}$ required less time to reach anthesis after the completion of cooling than at 10 or $18{ }^{\circ} \mathrm{C}$ (Fig. 2A, C). For 5 or 6 weeks of cooling, plants reached anthesis faster after treatment at 15 or $18{ }^{\circ} \mathrm{C}$ than at 10 or $13{ }^{\circ} \mathrm{C}$. There was much greater variation within treatments in time required to reach anthesis from the completion of cooling at $18{ }^{\circ} \mathrm{C}$ than at all the other cooling temperatures (data not shown). The SE for time to anthesis from the completion of cooling at $18{ }^{\circ} \mathrm{C}$ for each duration was approximately four times that at 10,13 , and $15^{\circ} \mathrm{C}$.

When cooling duration was extended from 2 to 6 weeks, time required to reach anthesis from the beginning of cooling treatments increased (Fig. 2B, D). With cooling duration lengthened from 2 to 6 weeks regardless of temperature, there was an increase of $16 \mathrm{~d}$ in time required to reach anthesis (from 63 to $79 \mathrm{~d}$ on average) from the beginning of cooling. Plants cooled at 10, 13 , or $15^{\circ} \mathrm{C}$ had more drastic changes in time to anthesis from the beginning of cooling with increasing cooling duration than those cooled at $18{ }^{\circ} \mathrm{C}$ (Fig. 2B, D). Changes in steepness of the linear slopes were observed in time required to reach anthesis from the beginning of cooling in response to cooling temperatures (Fig. 2B), decreasing from 5.2, $5.1,4.0$, to 2.4 for treatments at $10,13,15$, and $18{ }^{\circ} \mathrm{C}$, respectively (significant linear regression at $P \leq 0.001$ ). Visual performance of the flowering plants 1 month after being removed from cooling is shown in Figure 3.

Similar results were obtained from the Weslaco experiment (Fig. 4). Regardless of cooling temperature, the average time needed to reach anthesis decreased (from 70 to $51 \mathrm{~d}$ ) after the completion of cooling as cooling duration increased from 3 to 7 weeks (Fig. 4A). When recorded from the beginning of cooling, increasing cooling duration from 3 to 7 weeks caused an increase of $7 \mathrm{~d}$ in time required to reach anthesis (from 93 to 100 d on average; Fig. 4B). Regardless of cooling duration, plants took more time to reach anthesis, from either the beginning (from 88 to $103 \mathrm{~d}$ ) or completion (from 52 to $68 \mathrm{~d}$ ) of cooling, as temperature increased from 15 to $21{ }^{\circ} \mathrm{C}$ (Fig. 4C, D).

Generally, increasing cooling duration from 2 to 6 weeks or 3 to 7 weeks led plants to reach anthesis faster from the completion of cooling; however, the increasing cooling duration actually extended the total time
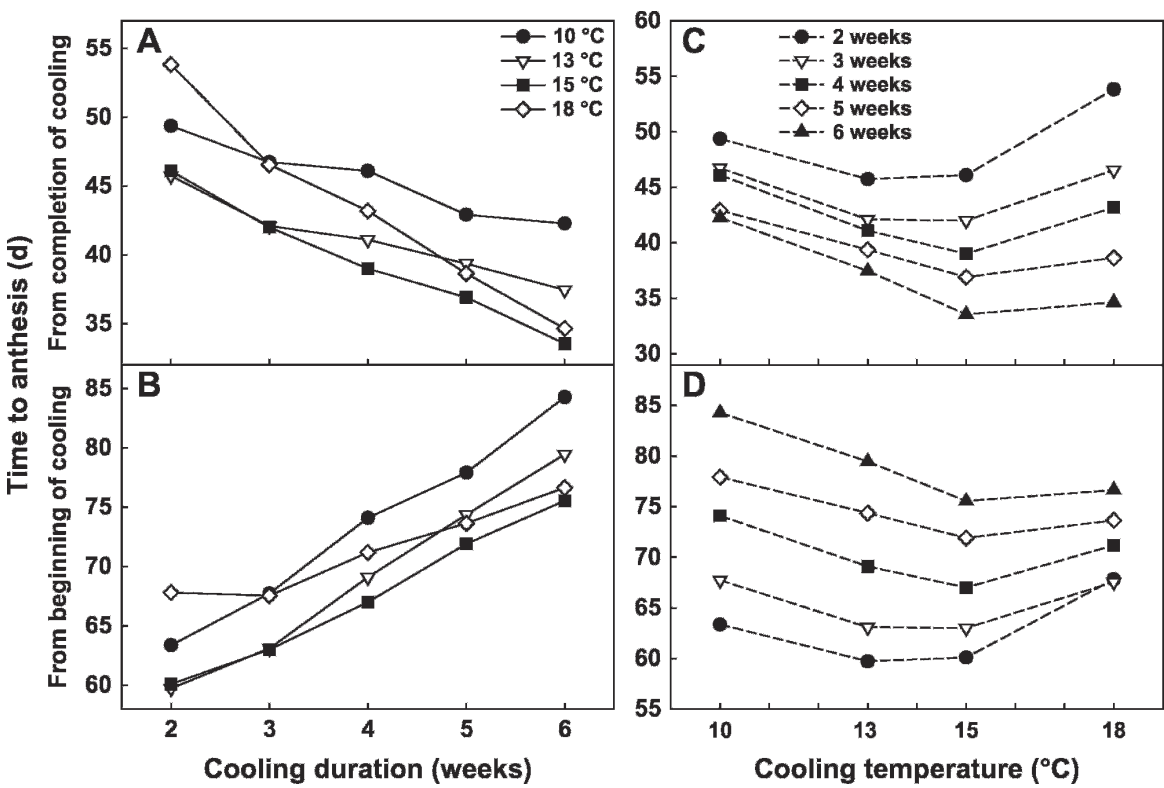

Fig. 2. Effects of cooling temperature and duration on time required to reach anthesis from completion $(\mathbf{A}, \mathbf{C})$ or beginning $(\mathbf{B}, \mathbf{D})$ of cooling in Dendrobium Sea Mary 'Snow King' in College Station.
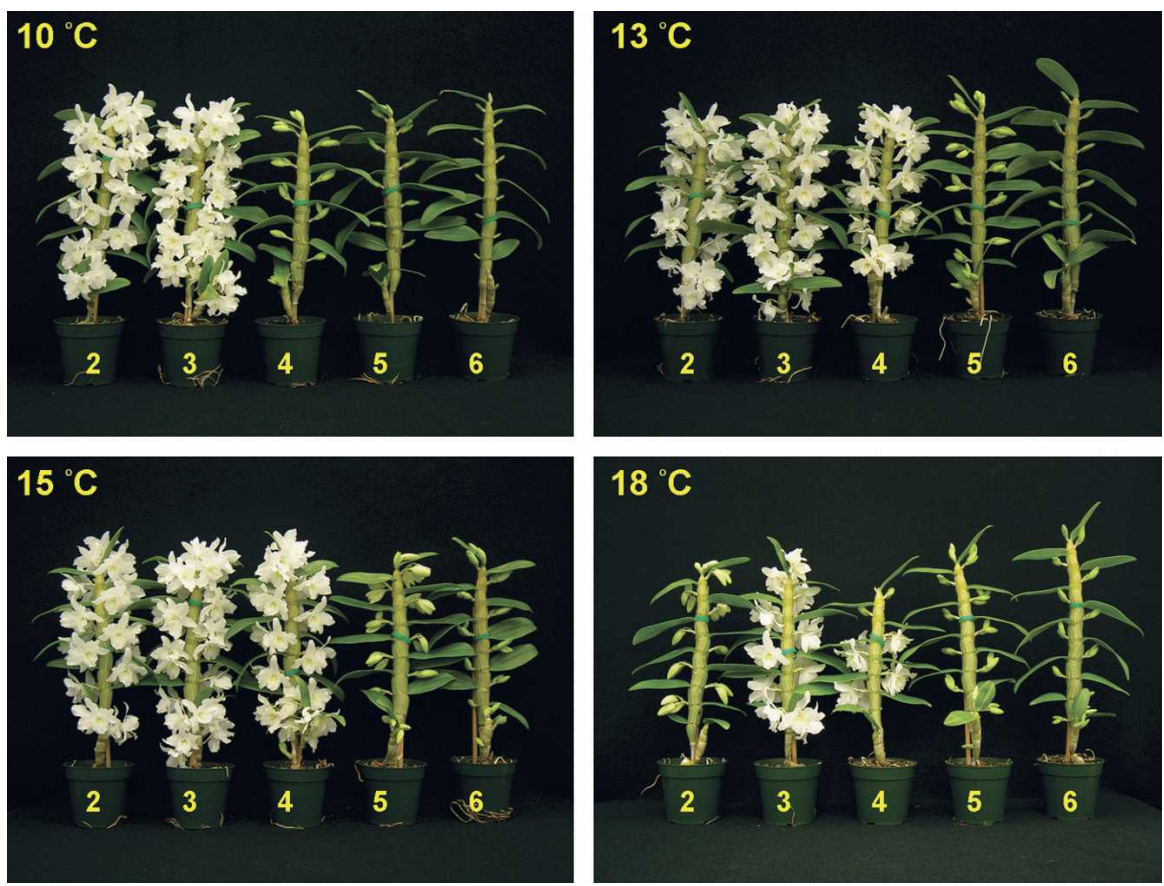

Fig. 3. Visual performance on 23 Jan. 2007 of Dendrobium Sea Mary 'Snow King' with various cooling temperatures and durations in College Station. Five cooling durations, beginning on 13 Nov. 2006, are numbered as 2 to 6 weeks.

required from the beginning of cooling to the stage of anthesis. Therefore, an extended duration at low temperatures would help extend the commercial availability of the crop.

In the College Station experiment, the interaction effect between temperature and cooling duration was significant on average flower number per flowering node. Flower number per flowering node stayed relatively stable $\approx 3.0$ as the duration of cooling increased at all temperatures except for $18{ }^{\circ} \mathrm{C}$ (data not shown). At $18^{\circ} \mathrm{C}, 2$ to 3 weeks of cooling resulted in a lower flower count of
2.5 per flowering node. However, temperature effect, instead of interaction effect, was significant on flower number per flowering node from the data collected in Weslaco. The highest cooling temperature of $21^{\circ} \mathrm{C}$ resulted in fewer flowers per flowering node than 15 or $18{ }^{\circ} \mathrm{C}$ (Table 1$)$.

Data from Weslaco showed a significant interaction effect between temperature and cooling duration on the number of nodes with aborted buds (Fig. 5). Plants cooled at $21^{\circ} \mathrm{C}$ had more drastic changes than at 15 or $18^{\circ} \mathrm{C}$ in percentage of nodes with aborted buds. 

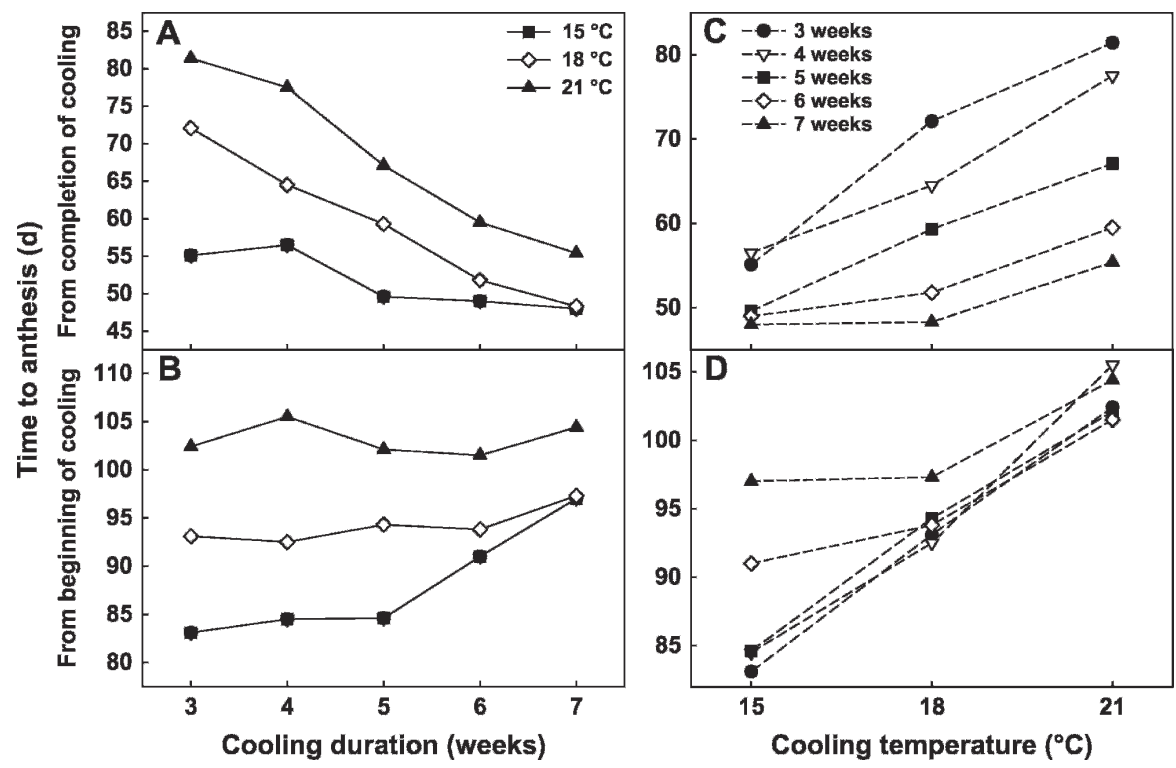

Fig. 4. Effects of cooling temperature and duration on time required to reach anthesis from completion (A, C) or beginning (B, D) of cooling in Dendrobium Sea Mary 'Snow King' in Weslaco.

Table 1. Effect of cooling temperature regardless of cooling duration on flower number per flowering node, nodes with flowers and total flower number of Dendrobium Sea Mary 'Snow King' in Weslaco.

\begin{tabular}{|c|c|c|c|c|}
\hline \multirow{2}{*}{$\begin{array}{l}\text { Cooling } \\
\text { temp }\left({ }^{\circ} \mathrm{C}\right)\end{array}$} & \multirow{2}{*}{$\begin{array}{l}\text { Flower number per } \\
\text { flowering node (no.) }\end{array}$} & \multicolumn{2}{|c|}{ Nodes with flowers } & \multirow{2}{*}{$\begin{array}{l}\text { Total flower } \\
\text { number (no.) }\end{array}$} \\
\hline & & No. & Percent & \\
\hline 15 & $2.5 \mathrm{a}^{\mathrm{z}}$ & $7.8 \mathrm{a}$ & $68.2 \mathrm{a}$ & $19.9 \mathrm{a}$ \\
\hline 18 & $2.5 \mathrm{a}$ & $7.9 \mathrm{a}$ & $68.3 \mathrm{a}$ & $19.4 \mathrm{a}$ \\
\hline 21 & $2.1 \mathrm{~b}$ & $6.9 \mathrm{~b}$ & $60.4 \mathrm{~b}$ & $14.8 \mathrm{~b}$ \\
\hline Significance & $* * *$ & $* * *$ & $* * *$ & $* * *$ \\
\hline
\end{tabular}

${ }^{\mathrm{z}}$ Means within columns followed by different letters are different.

**** Significant at $P \leq 0.001(\mathrm{n}=75)$.

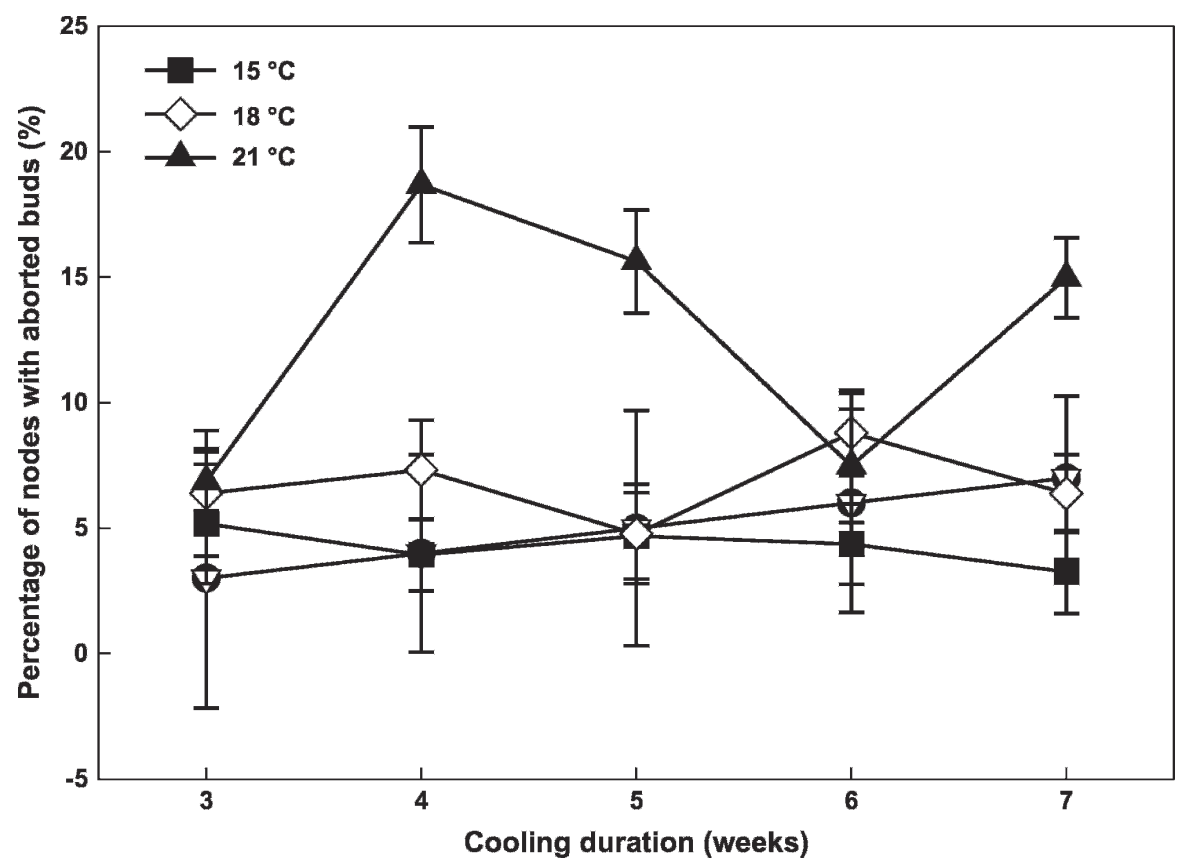

Fig. 5. Effects of cooling temperature and duration on percentage of nodes with aborted buds in Dendrobium Sea Mary 'Snow King' in Weslaco. Bars indicate \pm SE of the mean.

Plants had $15 \%$ to $19 \%$ of nodes with aborted buds when cooled for 4,5 , or 7 weeks at $21{ }^{\circ} \mathrm{C}$ versus $3 \%$ to $9 \%$ of the nodes in all other treatments.
All plants except for the observational control group flowered without producing aerial shoots. Even the least amount of cooling, 2 weeks at $18{ }^{\circ} \mathrm{C}$ or 3 weeks at $21^{\circ} \mathrm{C}$, was enough to trigger flower initiation. Plants that were removed from growth chambers after 2 weeks of cooling at all temperatures had obvious ( $2 \mathrm{~mm}$ or greater) protruding lateral buds developing during the ensuing week. Regardless of cooling duration, decreasing cooling temperature from 18 to $10{ }^{\circ} \mathrm{C}$ (Table 2) or from 21 to $15{ }^{\circ} \mathrm{C}$ (Table 1) improved flower counts. Plants had more flowering nodes, percentage of nodes with flowers, and total flower number when cooled at 10, 13, or $15{ }^{\circ} \mathrm{C}$ than $18{ }^{\circ} \mathrm{C}$ in College Station or at $15,18{ }^{\circ} \mathrm{C}$ than $21^{\circ} \mathrm{C}$ in Weslaco.

\section{Discussion}

The nobile dendrobium requires a period of cooling to trigger flower differentiation. Flowering in D. nobile was shown to be promoted by low temperatures ranging from 13 to $16^{\circ} \mathrm{C}$ and not above $18^{\circ} \mathrm{C}$ (Rotor, 1952 , 1959). A closely related descendant, $D$. Sea Mary 'Snow King', also needs to be subjected to a specific amount of cooling for flowering.

The specific amount of cooling (i.e., temperature and duration) constitutes the threshold to initiate flowering of nobile dendrobiums. Below the threshold, plants may fail to initiate flowers and aerial shoots may arise. Above the threshold, flowering occurs but flower quality and flowering speed would vary with the amount of cooling. The data indicated that the least amount of cooling, 2 weeks at $18{ }^{\circ} \mathrm{C}$ or 3 weeks at $21^{\circ} \mathrm{C}$, was above the threshold for triggering flower initiation in $D$. Sea Mary 'Snow King'. Sinoda et al. (1988) reported that aerial shoots were formed when buds were subjected to insufficient cooling (above $20^{\circ} \mathrm{C}$ ) in $D$. Snowflake 'Red Star'. In the current study, observational control plants without cooling failed to flower and produced aerial shoots.

In $D$. Hinode 'Toutenkou' and $D$. Snowflake 'Red Star', when cooling with low temperatures of 7.5 to $15{ }^{\circ} \mathrm{C}$ at night, high temperatures above $20{ }^{\circ} \mathrm{C}$ during daytime hindered flower development and reduced the flowering nodes (Sinoda et al., 1988). In the current study, plants cooled at 21 or $18{ }^{\circ} \mathrm{C}$ had fewer flowering nodes and total flowers. Regardless of temperature, cooling plants for an increasingly longer duration from 2 to 6 weeks resulted in slightly lower leaf retention (Yen, 2008). Therefore, cooling plants at 10,

Table 2. Effect of cooling temperature regardless of cooling duration on nodes with flowers and total flower number of Dendrobium Sea Mary 'Snow King' in College Station.

\begin{tabular}{lccc}
\hline $\begin{array}{l}\text { Cooling } \\
\text { temp }\left({ }^{\circ} \mathrm{C}\right)\end{array}$ & \multicolumn{2}{c}{ Nodes with flowers } & $\begin{array}{c}\text { Total flower } \\
\text { nomber (no.) }\end{array}$ \\
\cline { 2 - 3 } & No. & Percent & numb. \\
\hline 10 & $9.4 \mathrm{a}^{\mathrm{z}}$ & $84.1 \mathrm{a}$ & $28.2 \mathrm{a}$ \\
13 & $9.6 \mathrm{a}$ & $83.8 \mathrm{a}$ & $29.7 \mathrm{a}$ \\
15 & $9.1 \mathrm{a}$ & $80.8 \mathrm{a}$ & $27.5 \mathrm{a}$ \\
18 & $8.4 \mathrm{~b}$ & $74.9 \mathrm{~b}$ & $23.0 \mathrm{~b}$ \\
Significance & $* * *$ & $* * *$ & $* * *$
\end{tabular}

${ }^{\mathrm{z}}$ Means within columns followed by different letters are different.

${ }^{* * * *}$ Significant at $P \leq 0.001(\mathrm{n}=60)$. 
13 , or $15^{\circ} \mathrm{C}$ for less than 6 weeks is suggested for producing nobile dendrobiums with an optimum leaf retention if that is preferred.

Time needed to reach anthesis may be altered by varying temperature and duration of cooling. The temperature used for flower initiation can affect the speed of subsequent flower bud development in nobile dendrobiums (Ichihashi, 1997) if left under such conditions once the cold requirement has been fulfilled, possibly because temperature generally affects the metabolic activity and the balance of respiration and photosynthesis (Hopkins, 1999). In the present study, regardless of cooling temperatures, plants treated with longer cooling durations required less time to reach anthesis after the completion of cooling.

However, an excessive amount (i.e., lower temperature and/or extended duration) of cooling delays flower development, so plants actually need more time to be grown as a flowering crop. Once the flowers have been initiated, the growing temperature affects the rate of subsequent growth and development of inflorescences. Anthesis could be advanced by increasing temperatures during inflorescence development (Rotor, 1952, 1959). Therefore, once the cooling requirement for flower initiation is saturated and floral primordia have been differentiated, removing plants from cooling back to a warm environment $\approx 24{ }^{\circ} \mathrm{C}$ accelerates the development of flower buds.

A cooling treatment that precisely meets the saturated cooling requirement for flowering helps to save the production cost in cooling without slowing flower development. For short cooling durations, low temperatures representing strong inductive treatments accelerate flower initiation and differentiation, so flowers begin to develop and reach anthesis at an earlier time. For long durations, continuously exposing the plants to low temperatures retards subsequent flower development. Therefore, by comparing the speed of flower development among treatments (Yen, 2008), it was identified that 3 weeks at $13{ }^{\circ} \mathrm{C}$ had saturated cooling requirement for achieving the best flowering performance (i.e., fast flower development with reasonable high flower count). Furthermore, because there was no significant difference in the total flower number, flowering nodes, or flower diameter among plants cooled at 13 or $15^{\circ} \mathrm{C}$ for 3 weeks, a decision to use either 13 or $15^{\circ} \mathrm{C}$ as the cooling temperature can be made to minimize the production cost in temperature control.

Manipulating temperature could be used to program flowering. Rotor $(1952,1959)$ found that $D$. nobile plants remained vegetative at $18^{\circ} \mathrm{C}$ and flowers were produced when plants were at $13{ }^{\circ} \mathrm{C}$ regardless of daylength. Therefore, it was reported that flowering may be delayed by growing the plants at $18{ }^{\circ} \mathrm{C}$ and maintaining this temperature until $\approx 4$ months before the desired flowering date, and then the temperature should be dropped for flower initiation (Rotor, 1952, 1959). Flower bud development may be hastened by using a higher temperature (temperature unspecified) after the buds have been initiated (Rotor, 1952, 1959). However, the experiment in Weslaco showed that the hybrid $D$. Sea Mary 'Snow King' was able to flower after being cooled at $21{ }^{\circ} \mathrm{C}$. Inhibitive temperatures for flower induction might vary among cultivars. In addition, such a programming approach simply by using the inductive or inhibitive temperatures for flowering is easy to execute, but continuously maintaining a high temperature long after pseudobulb maturation to prevent flower initiation may cause the axillary buds to form aerial shoots. It has been reported that day temperature above $25{ }^{\circ} \mathrm{C}$ promotes aerial shoot formation in $D$. Snowflake 'Red Star' (Sinoda et al., 1988).

From the current study of $D$. Sea Mary 'Snow King', using various temperatures from 10 to $18{ }^{\circ} \mathrm{C}$ in College Station or from 15 to $21{ }^{\circ} \mathrm{C}$ in Weslaco effectively extended the time to reach anthesis for a period of 24 or $23 \mathrm{~d}$, respectively. Consequently, using various temperatures from 10 to $21^{\circ} \mathrm{C}$ that delay or accelerate flower development after initiation may be another way to program flowering. Such an approach may be especially useful when commercial growers manage to meet specific market dates. For example, if cooling treatments start in mid-October, growers can meet the Christmas market by cooling mature plants for 2 weeks at 13 or 15 ${ }^{\circ} \mathrm{C}$, the New Year's market by using 3 weeks at $18{ }^{\circ} \mathrm{C}$, and the market of Valentine's Day by using 4 weeks at $21{ }^{\circ} \mathrm{C}$. However, growth and development vary depending on cultivar, greenhouse environment, fertilization, season, and so on. Similar experiments evaluating cooling temperature and duration response would be required to program flowering of additional nobile dendrobium cultivars or under a different growing environment.

In the current studies, all cooling treatments were able to initiate flowering. The higher 18 or $21^{\circ} \mathrm{C}$ cooling treatments caused a less desirable flowering quality with fewer flowering nodes and fewer total flowers. Three weeks at 13 or $15^{\circ} \mathrm{C}$ is a recommended cooling treatment that saves production cost without retarding flower development in
$D$. Sea Mary 'Snow King'. However, various combinations of cooling temperature and duration that delay or accelerate flowering may help to program flowering to meet a specific market time.

\section{Literature Cited}

Arditti, J. 1966. Flower induction in orchids. Orchid Rev. 74:208-217.

Baker, M.L. and C.O. Baker. 1996. Orchid species culture: Dendrobium. Timber Press, Portland, OR.

Chen, W.S., H.Y. Liu, Z.H. Liu, L. Yang, and W.H. Chen. 1994. Gibberellin and temperature influence carbohydrate content and flowering in Phalaenopsis. Physiol. Plant. 90:391-395.

Goh, C.J., M.S. Strauss, and J. Arditti. 1982 Flower induction and physiology in orchids, p. 213-241. In: Arditti, J. (ed.). Orchid biology: Reviews and perspectives, II. Cornell Univ. Press, Ithaca, NY.

Hopkins, W.G. 1999. Introduction to plant physiology. 2nd ed. Wiley, New York, NY.

Ichihashi, S. 1997. Orchid production and research in Japan, p. 171-212. In: Arditti, J. and A.M. Pridgeon (eds.). Orchid biology: Reviews and perspectives, VII. Kluwer Academic Publishers, Dordrecht, The Netherlands.

Laws, N. 2004. The world's fascination with potted orchids. FloraCult. Intl. 14:26-27.

Nishimura, G., K. Kosugi, and J. Furukawa. 1976. Flower bud formation in Phalaenopsis. Orchid Rev. 84:175-179.

Rotor, G.B., Jr. 1952. Daylength and temperature in relation to growth and flowering of orchids. Cornell Expt. Sta. Bul. 885.

Rotor G.B., Jr. 1959. The photoperiodic and temperature response of orchids, p. 397-417. In: Withner, C.L. (ed.). The orchids, a scientific survey. Ronald Press, New York, NY.

Sakanishi, Y., H. Imanishi, and G. Ishida. 1980. Effect of temperature on growth and flowering of Phalaenopsis amabilis. Bul. Univ. Osaka Prefecture, Ser. B, Agr. Biol. 32:1-9.

Sinoda, K., K. Suto, M. Hara, and M. Aoki. 1988. Effect of day and night temperature on the flowering of Dendrobium nobile-type cultivars [in Japanese]. Bul. Natl. Res. Inst. Veg. Ornamental Plants Tea, Ser. A. 2:279-290.

Tran Thanh Van, M. 1974. Methods of acceleration of growth and flowering in a few species of orchids. Amer. Orchid Soc. Bul. 43:699-707.

U.S. Department of Agriculture. 2007. Floriculture crops 2006 summary. U.S. Dept. Agr., Washington, DC.

Wang, Y.T. 2004. Flourishing market for potted orchids. FlowerTech 7:2-5.

Wang, Y.T., W.T. Tsai, and T.E. Dai. 2006. Heavy shading-An effective, low-cost alternative to high temperatures for inhibiting spiking in Phalaenopsis. Proc. Taiwan Intl. Orchid Symp. p. $164-173$.

Yen, C.Y.T. 2008. Effects of nutrient supply and cooling on growth, flower bud differentiation, and propagation of the nobile dendrobium orchid. Texas A\&M Univ., College Station. MS Thesis. 